\title{
A Survey on Awareness about Pharmacovigilance among Community Pharmacists in Resource Limited Settings of India \\ Original Article
}

\section{Authors \\ *Nasr Khallafallah Nasr Elhidrbi ${ }^{1}$, Mouaid Mohamed Eltayeb ${ }^{1}$, Tirupa $\mathbf{M}^{2}$, Dr Mohanraj Rathinavelu ${ }^{3}$, Dr. Y. Padmanabha Reddy ${ }^{4}$}

${ }^{1}$ II Year Student, Masters of Pharmacy, Department of Pharmacy Practice, Raghavendra Institute of Pharmaceutical Education \& Research, RIPER, Ananthapuramu, Andhra Pradesh, India - 515721

${ }^{2}$ Pharm. D Intern, Doctor of Pharmacy, Department of Pharmacy Practice, Raghavendra Institute of Pharmaceutical Education \& Research, RIPER, Ananthapuramu, Andhra Pradesh, India - 515721

${ }^{3}$ Assistant Professor \& In-Charge, Department of Pharmacy Practice, Raghavendra Institute of Pharmaceutical Education \& Research, RIPER, Ananthapuramu, Andhra Pradesh, India - 515721

${ }^{4}$ Professor \& Principal, Raghavendra Institute of Pharmaceutical Education \& Research,

RIPER, Ananthapuramu, Andhra Pradesh, India - 515721

*Corresponding Author

\section{Mr. Nasr Khallafallah Nasr Elhidrbi}

II Year Student, Masters of Pharmacy, Department of Pharmacy Practice, Raghavendra Institute of Pharmaceutical Education \& Research, RIPER, Anantapuramu, Andhra Pradesh, India - 515721

Email: machomoley@gmail.com Cell no: +918897903917

\section{ABSTRACT}

Over the past four decades there has been a trend for pharmacy practice to move away from its original focus on medicine supply towards a more inclusive focus on patient care. Due to the introduction of a large number of potent toxic chemicals as drugs in the last two or three decades the detection of adverse drug reactions (ADRs) has become increasingly significant. Physicians, pharmacist and nurses are in a position to play a major key role in pharmacovigilance programs. The current cross sectional questionnaire survey of six months duration was designed to assess the pharmacovigilance awareness among the pharmacists in community settings in a resource limited settings of south India by administering a Pre-designed questionnaire. Among the 120 pharmacists working in community settings only 80\% (96) provided their responses. Of the responses $75 \%$ (72) were analyzed and the rest were not included in the analysis because of incomplete information. This study showed little awareness about the Pharmacovigilance system among the pharmacists in community settings of resource limited setting in south India. The pharmacists primarily did not know the definition and purpose of Pharmacovigilance. In conclusion, Community Pharmacists have very little basic knowledge about pharmacovigilance. The simulations about pharmacovigilance can be incorporated in the syllabus of diploma and degree curriculum of pharmacy by Pharmacy Council of India (PCI) by which the practice of pharmacy and pharmaceutical care concepts can be well established.

Keywords: Community pharmacists, cross sectional survey, pharmacovigilance, professional practice. 


\section{INTRODUCTION}

Over the past four decades there has been a trend of pharmacy practice to move away from its original focus on medicine supply towards a more inclusive focus on patient care. The role of the pharmacist has evolved from that of a compounder and supplier of pharmaceutical products towards that of a provider of services and information and ultimately that of a provider of patient care. This new approach has been given the name pharmaceutical care defined as the responsible provision of drug therapy for the purpose of achieving definite outcomes that improve a patient's quality of life" (Hepler and Strand, 1990) ${ }^{[1]}$. In adopting this definition in 1998, the International Pharmaceutical Federation (FIP) added one significant amendment: "achieving definite outcomes that improve or maintain a patient's quality of life." The concept of the seven-star pharmacist, introduced by WHO (World Health Organization) and taken up by FIP in 2000 in its policy statement on Good Pharmacy Education Practice, sees the pharmacists as a caregiver, communicator, decision-maker, teacher, life-long learner, leader and manager ${ }^{[2]}$.

Medication safety is a more significant issue, because of immense competition among pharmaceutical manufacturers; medicinal products may be registered and marketed in many countries simultaneously. As a result, adverse reactions may not always be readily identified and so are not monitored systematically. Pharmacovigilance is a systematic and structured process for the monitoring and detection of adverse drug reactions (ADRs) in a given context ${ }^{[3]}$.

Pharmacovigilance has constantly grown its importance in last 15 years, relating to the absolute amount of adverse drug reactions (ADRs) and to the fact of several hospital admissions are due to ADRs ${ }^{[4][5]}$.

The success of a pharmacovigilance program depends upon the involvement of the healthcare professionals and reporting the ADRs. Providing information on suspected ADRs is as much a moral duty for the doctor as other aspects of patient care ${ }^{[6]}$.

The community pharmacist's role is to promote the development, maintenance and ongoing evaluation of a program to reduce the risks of ADRs by detecting, reporting and assessing any suspected ADRs. A pharmacist can educate the physicians and nurses and can encourage compliance with the ADR reporting program ${ }^{[7]}$.

The literatures reported that community pharmacists can play a vital and supportive role in ADR reporting because they are considered as the first point of contact within the health care system and daily contact with patients makes them ideally placed to learn of possible ADRs ${ }^{[8]}$.

Pharmacovigilance is still in its infancy in India and there exists very limited knowledge about this discipline. However, the Indian national Pharmacovigilance programme lacks continuity due to lack of awareness and inadequate training about drug safety monitoring among healthcare professionals in India ${ }^{[9]}$. Therefore this study was conducted to assess awareness of pharmacovigilance among the community pharmacists in Anantapur, Andhra Pradesh., India.

\section{MATERIAL \& METHODS}

Study design: Cross sectional, questionnaire based survey.

Study site: The study was carried out among registered pharmacists working in community backgrounds of a resource limited settings of India.

Study Period: 06 Months.

Study Population \& Sampling: 72 Registered pharmacists.

\section{Study Criteria}

Inclusion criteria: Registered pharmacists with qualification of

- D.Pharmacy

- B.Pharmacy was included in study.

\section{Exclusion Criteria:}

- Pharmacy technicians and assistants with no eligible qualification were being excluded. 


\section{Study Tools \& Procedure:}

The study instrument was a pre-designed questionnaire which was structured to obtain information on the knowledge about Pharmacovigilance and Adverse Drug Reactions (ADRs).

Questionnaire: The questionnaire was adapted from a similar study investigating the knowledge and practice of Pharmacovigilance and ADR reporting. It was designed to capture the information contained two sections comprising of demographic data and questions on knowledge on pharmacovigilance. Questionnaire was prepared and evaluated by the faculties' expertise in the field of drug use and research and ADR reporting and monitoring studies of Raghavendra Institute of Pharmaceutical Education \& Research (RIPER) Anantapuramu, Andhra Pradesh., India.

\section{RESULTS \& DISCUSSION}

Among the 120 pharmacists working in community settings only $80 \%$ (96) provided their responses. Of the responses $75 \%$ (72) were analyzed and the rest were not included in the analysis because of incomplete information. Demographic details of the participants involved in the study was categorized based on gender distribution, age distribution, educational qualification, the results of which were thoroughly analyzed and reported in Table 1 (Demographic details of the participants).

Table. 1. Demographic Details

\begin{tabular}{|c|c|c|c|c|}
\hline S. no & Demographic details & \multicolumn{3}{|c|}{$\begin{array}{l}\text { No. of Participants } \\
(n=72)\end{array}$} \\
\hline \multirow[t]{2}{*}{01} & $\begin{array}{l}\text { Gender Distribution } \\
\text { A. Male }\end{array}$ & \multicolumn{3}{|c|}{$56(77.78 \%)$} \\
\hline & B. Female & \multicolumn{3}{|c|}{$16(22.22 \%)$} \\
\hline \multirow[t]{5}{*}{02} & Age Distribution & $(n=72)$ & Male & Female \\
\hline & $22-30$ & 18 & 12 & 06 \\
\hline & $31-40$ & 32 & 25 & 07 \\
\hline & $41-50$ & 13 & 10 & 03 \\
\hline & $>50$ & 09 & 09 & - \\
\hline \multirow[t]{3}{*}{$\mathbf{0 3}$} & Educational Qualification & $(\mathrm{n}=72)$ & Male & Female \\
\hline & D. Pharmacy & 54 & 43 & 11 \\
\hline & B. Pharmacy & 18 & 13 & 05 \\
\hline
\end{tabular}

This study showed little awareness about the Pharmacovigilance system among the pharmacists in community settings of resource limited setting in south India. The pharmacists primarily did not know the definition and purpose of Pharmacovigilance. Since, the questionnaire comprises of details regarding functions and field of pharmacovigilance in choices most of the pharmacists replied it with option of ALL which was correct. The response of the participants to the pre-designed questionnaire was reported in Table. 2 (Responses to the Pre-designed Questionnaire). 
Table. 02 Responses to the Pre-designed Questionnaire

\begin{tabular}{|c|c|c|c|c|}
\hline S.no & Questions & Right Answer & $\begin{array}{l}\text { Positive } \\
\text { response }\end{array}$ & $\begin{array}{l}\text { Negative } \\
\text { response }\end{array}$ \\
\hline 01 & Define Pharmacovigilance & $\begin{array}{l}\text { The detection, assessment, } \\
\text { understanding \& prevention } \\
\text { of adverse effects }\end{array}$ & $\begin{array}{c}18 \\
(25 \%)\end{array}$ & $\begin{array}{c}54 \\
(75 \%)\end{array}$ \\
\hline 02 & $\begin{array}{l}\text { The important purpose of } \\
\text { Pharmacovigilance is }\end{array}$ & To identify safety of drugs & $\begin{array}{c}15 \\
(20.83 \%)\end{array}$ & $57(79.17 \%)$ \\
\hline 03 & $\begin{array}{c}\text { The functions of } \\
\text { Pharmacovigilance are }\end{array}$ & All of the above & $\begin{array}{c}60 \\
(83.33 \%)\end{array}$ & $\begin{array}{c}12 \\
(16.67 \%)\end{array}$ \\
\hline 04 & Pharmacovigilance includes & All & $60(83.33 \%)$ & $\begin{array}{c}12 \\
(16.67 \%)\end{array}$ \\
\hline 05 & $\begin{array}{c}\text { National pharmacovigilance } \\
\text { program in India is governed by }\end{array}$ & $\begin{array}{l}\text { CDSCO under the aegis of } \\
\text { Health and Family Welfare }\end{array}$ & $\begin{array}{c}16 \\
(22.22 \%) \\
\end{array}$ & $\begin{array}{c}56 \\
(77.78 \%) \\
\end{array}$ \\
\hline 06 & $\begin{array}{l}\text { National Pharmacovigilance } \\
\text { Programme (NPP) of India was } \\
\text { officially inaugurated in the year: }\end{array}$ & New Delhi, 2004 & $\begin{array}{c}18 \\
(25 \%)\end{array}$ & $\begin{array}{c}54 \\
(75 \%)\end{array}$ \\
\hline 07 & $\begin{array}{c}\text { The chairman of } \\
\text { Pharmacovigilance program in } \\
\text { India }\end{array}$ & $\begin{array}{l}\text { DCGI (Drug Controller } \\
\text { General of India) }\end{array}$ & $\begin{array}{c}21 \\
(29.17 \%)\end{array}$ & $\begin{array}{c}51 \\
(70.83 \%)\end{array}$ \\
\hline \multirow[t]{2}{*}{08} & \multirow{2}{*}{$\begin{array}{c}\text { Are you aware of existence of } \\
\text { NPC in India }\end{array}$} & YES & \multicolumn{2}{|c|}{ NO } \\
\hline & & 30 & \multicolumn{2}{|c|}{42} \\
\hline 09 & If yes, then where is it located: & $\mathrm{CDSCO}$ & 18 & 54 \\
\hline \multirow[t]{2}{*}{10} & $\begin{array}{c}\text { Do you know that community } \\
\text { Pharmacist is one of the }\end{array}$ & YES & \multicolumn{2}{|c|}{ NO } \\
\hline & $\begin{array}{c}\text { responsible healthcare } \\
\text { professionals to report ADRs }\end{array}$ & $39(54.17 \%)$ & \multicolumn{2}{|c|}{$33(45.83 \%)$} \\
\hline
\end{tabular}

The response to the Governance and inauguration of National Pharmacovigilance Programme (NPP) India was very negative. Therefore, it seems necessary to hold awareness programmes to improve the education of pharmacists in community settings regarding the current scenario of pharmacy practice in India and its future perspective.

The pharmacist should also be encouraged for the ADRs reporting, since they are in closer contact with the patients for a longer duration and as they can play an important role in making the pharmacovigilance programs more efficacious.

\section{CONCLUSION}

In conclusion, community pharmacists have very little basic knowledge about pharmacovigilance. The simulations about pharmacovigilance can be incorporated in the syllabus of diploma and degree curriculum of pharmacy by Pharmacy Council of India (PCI) by which the practice of pharmacy and pharmaceutical care concepts can be well established. The pharmacist in community setting practice can also contribute to the patient care with good health outcome benefit and safety use of medication rationally.

\section{ACKNOWLEDGEMENTS}

The author would like to express sincere thanks to Dr. Katta Anand, President - Chemists \& Druggist Association, Anantapur, Andhra Pradesh, India, Mr. Hari Hara Teja Duga, Drug Inspector for providing the platform for interacting with all the community pharmacists. 


\section{REFERENCES}

1. Hepler CD, Strand LM. Opportunities and responsibilities in pharmaceutical care. Am J Hosp Pharm 1990; 47:533-43.

2. The role of the pharmacist in the health care system. Preparing the future pharmacist: Curricular development. Report of a third WHO Consultative Group on the role of the pharmacist, Vancouver, Canada, 27-29 August 1997. Geneva: World Health Organization; 1997. WHO/PHARM/97/599. Available at: http: //www.who.int/medicinedocs/

3. WHO policy perspectives on medicines. Pharmacovigilance: ensuring the safe use of medicines. Geneva: world health organization; 2004. Available at http://www.who.int/medicines/.

4. Von Laue NC, Schwappach DL, Koeck CM. The epidemiology of preventable adverse drug events: a review of literature. Wien Klin Wochenschr 2003 July 15; 115(12):407-15.

5. $\mathrm{Wu} \mathrm{WK}$, Pantaleo $\mathrm{N}$ et al Evaluation of outpatient adverse drug reactions leading to hospitalization. Am J Health Syst Pharm 2003 February 1; 60(3):253-9.

6. Faich GA. Adverse-drug-reaction monitoring. $\mathrm{N}$ Engl J Med. 1986; 314(24):1589-1592.

7. ASHP guidelines on adverse drug reaction monitoring and reporting. Am J Health Syst Pharm. 1995; 52(4):417 419

8. Christropher F. Green, David R. Mottram, Philip H. Rowe, Munnir Pirmohammed, Attitudes and Knowledge of hospital Pharmacists to adverse drug reaction reporting, BJCP; Volume 51, Issue 1, page 81 - 86, January 2001.

9. Rajesh R, Vidyasagar S, Nandakumar K. Highly active antiretroviral therapy induced adverse drug reactions in Indian human immunodeficiency virus positive patients. Pharmacy Practice 2011 JanMar; 9(1):48-55. 